\title{
Electronic Government and Web 2.0 in Brazil: the Reality of Some Municipalities in the State of Minas Gerais with Low HDI
}

\author{
Luana Martins Oliveira, Jeferson Gomes dos Santos, Joao Paulo Calembo \\ Batista Menezes
}

Dept. of Public Administration at Federal University of Jequitinhonha e Mucuri Valleys-UFVJM, Brazil.

\begin{abstract}
Due to various transformations that have occurred in society since the advent of globalization and Information and Communication Technologies (ICTs), this research has the objective of analyzing the relevance of the electronic participation in the democratic context and to present the availability of web 2.0 tools intended for the participation on the websites of the prefectures of Mucuri Valley Mesoregion with low levels of Human Development Index, since ICTs can foster and broaden the forms of interaction between the State and Society. Electronic Government, based on electronic participation tools, can provide citizens with greater involvement in the decision-making aspects of public organizations, establishing a favorable scenario for democracy. The data collection was based on methods of content analysis, specifically an oriented internet browsing. At the end of the research the tools that are made available by city halls were presented and compared. Most municipalities in the Mucuri Valley Mesoregion use sites as e-government tools, three prefectures do not have electronic tools to disseminate and exchange information with citizens, and eight of them have no web 2.0 tools, demonstrating the slow digital evolution in some Brazilian municipalities.
\end{abstract}

Keywords: Electronic Government, Web 2.0, ICTs, Public transparency, Citizen Participation.

\section{Introduction}

The current historical moment, known as the information age [1] and the time of a globalized world [2], leads governments everywhere to get adapted to the use of new technologies in which Information and Communication Technologies (ICTs) play a fundamental role in the modernization of relations between government, companies and citizens.

By 2016, the digital gap between countries is still lingering, since the level of Internet penetration in developed countries is $81 \%$, while in emerging and in the poorest ones are respectively at $40 \%$ and $15 \%$. However it should be noted that in the same report it is shown that the access via cell phone is widespread and, with the coverage of $95 \%$ of the global population, the internet use has been widespread [3].

This context forges a new reality for the citizens as the evolution of informatics proposes a new paradigm of relationship between State and Society, based on a proposal of greater democracy and transparency [4].

Electronic Government, which represents access to government services and information via digital means, contributes to the citizens' participation in the public administration along with the government through electronic means, so that the communication between these two happens more quickly [5].

In Brazil 54\% of households are already connected to the internet [6]. This new arrangement allows citizens to be more involved in the decision-making aspects of public organizations, setting the stage for an effective democracy. Citizen participation provided by electronic means [7] can be perceived as sustained not only by the popular will to enjoy these means, but also by the commitment of government programs to foster this involvement. In order to consolidate such structure it is necessary the existence of instruments that facilitate and 
foster this participatory process, so that democracy becomes more complete and profound. The Brazilian governments in their three levels (Federal, State and Municipal) must develop mechanisms (financial, technological and intellectual resources) that propitiate the development of e-government tools.

The objective of this study is to analyze the relevance of electronic participation in the democratic context and to present the provision of tools for the citizen participation in the Brazilian context, specifically on the sites of prefectures of Mucuri Valley Mesoregion in the State of Minas Gerais considering low levels of Human Development Index.

\section{Review of Literature}

\section{Electronic Government: A Concept under Construction}

The main asset of the current society is the use of technological and digital means to carry out the vast majority of its actions, and in this context, the use of the Internet stands out, which enabled the circulation of information and services in accelerated levels, which has directed humanity to new behaviors.

The way in which the State appropriates modern ICT tools for its implementation in the public administration is revealed in the provision of information among government bodies, companies and citizens, and is better known as Electronic Government [8].

A true transformation of social life derive from the application of these technologies [9], because its impact reaches diverse contexts, including the political one, since it allows the existence of new means for the people to organize themselves politically, reaching even those who were disinterested.

In this sense, Information and Communication Technologies (ICTs) can have political and democratic purposes for a number of sectors of society, among which are citizens, government organizations, civil society, and political parties, among others. The introduction of these new means leads to the expansion of citizen participation in processes of discussion and political deliberation, thus democratizing decisionmaking processes [8]. The use of Electronic Government strategies allows the improvement of public administration processes, and through automation it is possible to perform and provide services in a faster and more efficient way, making it easier also to check and to monitor the results. The citizen can access information and services without leaving home, reducing the physical structure and the quantity of personnel necessary to assist in public agencies [10].

Electronic government represents more than a website, an e-mail or other electronic transaction via the Internet [11]. It is the natural evolution from the technological revolution that emerged with the knowledge society. Electronic Government comes as a strategy for cost reduction and rapprochement between agents (government, citizens and companies). The relationship between Government and Citizen is abbreviated in G2C; G2B refers to the relationship between government and business; G2G makes reference to the relations between the entities and departments of the government [11].

The digital environment offers new opportunities, facilitating the exchange of information between agents. It allows for more collaborative and participatory relationships between stakeholders (G2C, G2B and G2G), and they can actively structure the political priorities, helping the design of public services and participation in their implementation, and also integrated solutions to complex challenges [12].

Electronic government aims to democratize access to information and participation of citizens in government actions. However, can implementing a technological structure for electronic government in a country really empower the democratic processes? This issue reveals some aspects that should be considered by the government at the time of planning an e-government project, because through it the information and services can be available 24 hours a day, 7 days a week; but, effectively, who has access to this infrastructure and has the knowledge and skills necessary to enjoy its functionality?

These issues reveal the need for effective planning when introducing e-government strategies. The government before executing an e-government project should ascertain whether it has the appropriate structure and 
whether the agents involved (citizens and companies) also have the necessary structure and knowledge to use the tools that will be made available [11].

Without adequate planning, Electronic Government, instead of favoring democracy, may lead to the exclusion of those who do not have access to sufficient technological structure to use the tools [13]. Electronic Government is a strategic tool to institute innovative, participatory and open public sectors, with the aim of improving social inclusion and governmental responsibility, as well as promoting the integration between governmental and non-governmental actors in favor of national development and, in the long term, sustainable growth [12].

\section{Electronic Government and Electronic Participation in the Web 2.0 Context}

The understanding we have about egovernment seeks to represent it by the changes that have taken place in the structures of the State and Public Administration through the use of ICTs, which should translate into services that are more citizen-oriented and capable of fostering citizen participation in government processes. In this way, the new technologies improve the public management with respect to their processes and in the approach and dialogue with the citizen.

Electronic participation can be considered as a citizen activity of a voluntary nature, and is carried out with the intention of influencing the public decisions of the rulers through electronic means [14]. The concept of electronic participation is associated with the partnership established between government and citizens in order to transact information and decision processes, which is effective with the elaboration of channels for efficient communication between the two.

The use of the internet to expand democratic spaces is very advantageous, since it is very dynamic, which facilitates the interaction and the processes of discussions for the creation of new policies [5]. Electronic Government policies should bring this dynamism to the public administration, since its composition was given both for the provision of services and for expansion of participation mechanisms [15].

Governmental sites can raise the public's right to participate in public administration decisions, since the use of these technological tools is able to bring citizen demands and the political agenda closer together, and may improve the relationship between government and citizens [16].It is noteworthy that [17] this citizen participation transcends the simple use of online public services.

Currently [18], e-government acts through websites to conceive its relationship with users, which access information and services, spaces that must offer transparency and channels of participation both in the elaboration and in the conduct of public policies.

In Brazil, since the internet was structured, ICTs are used to raise the quality of public services, and since then e-government has been trying to align itself with the policies of cost reduction, accountability to the population, and the provision of services and information to the citizens [19].

Specifically in the case of Brazil there is a legal framework that guarantees citizens access to information from public agencies, which is the law on access to information, of November 18, 2011, and it is something important for the solidification of democracy.

However, e-government goes beyond access to information, as it enhances the democratic process [20], through the use of some digital devices, applications and tools that supplement the practice of political participation. The effectiveness of citizen's participation is highlighted at local levels. However, it can be recognized that these new technological devices extend interaction and co-decision to all spheres of the State [15].

In order to improve the processes of interaction between government and citizens [19], websites should be a digital environment equipped with tools and devices that open space for citizen participation, where they can express opinions on public policies and lead public administrators to actions that best fit the population demands. It must be taken into account that, in a preponderant way, the internet has evolved into a more open format, a digital context known as web 2.0. If, on the other hand, web 1.0 worked with more rigid and ready standards, web 2.0 revolutionized with its openness and flexibility, which pushed potential users to participation and collaboration. 
It is emphasized by [21] that web 2.0 is a platform where several applications are provided free of charge. This is evidenced by the existence of blogs, wikis, multimedia sharing services, RSS, podcasting and social networks [22].

In this new digital scenario the internet is even more present in people's lives, and since the transformation of web 2.0 the user has a more active voice in contemporary society through this mechanism [23]. Thus, the citizen has become freer to participate in the discussions, having more conditions to investigate matters of interest to him and, when this user finds some information of his interest, he has the opportunity to share with his social network, or else to criticize determined action or entity through the social network in which he is a participant [23].

At this juncture, social networks stand out, which has great impact power, due to its capacity of aggregation of large numbers of users. They are a new space for exhibitions and publications [24], which should be explored, and be included in the guidelines of communication strategies of organizations, including those that integrate public administration, since it is a new Paradigm of citizenship [25].

In this scenario, the public administration should consider the use of these new digital standards, in order to promote the strengthening of citizenship through the greater proximity of citizens to public policies.

\section{Research Methodology}

The data collection was done through a search in "Google" search site to identify the sites of prefectures of Mucuri Valley mesorregion, which covers 23 Brazilian municipalities: Águas Formosas, Ataléia, Bertópolis, Carlos Chagas, Catuji, Crisólita, Franciscopolis, Frei Gaspar, Fronteira dos
Vales, Itaipé, Ladainha, Machacalis, Malacacheta, Nanuque, Novo Oriente de Minas, Ouro Verde de Minas, Pavão, Poté, Santa Helena de Minas, Setubinha, Serra dos Aimorés, Teófilo Otoni e Umburatiba.

The surveys were carried out by the "name of the municipality" (for example: Águas Formosas) and "prefecture of (name of the municipality)" (for example: Águas Formosas prefecture). After the identification of the sites, the data collection continued through the internet browsing method oriented on the sites of the city halls to verify the tools of Electronic Government and identification of the tools of electronic participation in web 2.0 that are made available to the citizens. Data collection was performed on March 26 and 27, 2017.

The analysis of observations made from internet browsing [28], was structured as followed [29]: a) to analyze the validity of the document for the research; b) to verify what contents are related to public management and electronic participation; c) to classify the documents; d) to elaborate tables and boards with the analysis of similarities and divergences in the ways in which the tools and spaces created by city halls have been made available.

In addition to the electronic participation tools provided by the city halls themselves, it was relevant to identify the use of web 2.0 platforms, such as forums, communities, social networks (Twitter, Facebook, Google+, Youtube, Flickr, Linkedin), chat and wiki, Which according to [30] are interactive instruments of easy location and free access to citizens.

\section{Results and Discussion}

Initially, from a research in search sites, there were identified the prefectures that had official website as initiative of Electronic Government practices. The table below presents the results of the survey:

Table 1: Incidence of sites in the municipalities of mucuri valley mesoregion

\begin{tabular}{|c|c|c|c|c|}
\hline Municipality & $\begin{array}{l}\text { HDI } \\
2010 \\
\end{array}$ & Population* & $\begin{array}{c}\text { Does it have an } \\
\text { official website? }\end{array}$ & Site \\
\hline ÁguasFormosas & 0,645 & 19.363 & Yes & http://aguasformosas.mg.gov.br/site/ \\
\hline Ataléia & 0,588 & 13.897 & Yes & http://www.ataleia.mg.gov.br/ \\
\hline Bertópolis & 0,594 & 4.671 & Yes & http://www.bertopolis.mg.gov.br/ \\
\hline Carlos Chagas & 0,648 & 19.857 & Yes & http://www.carloschagas.mg.gov.br/site/ \\
\hline Catuji & 0,540 & 6.646 & Yes & http://www.catuji.mg.gov.br/ \\
\hline Crisólita & 0,585 & 6.579 & Yes & http://www.crisolita.mg.gov.br/ \\
\hline Franciscópolis & 0,603 & 5.708 & No & N/A \\
\hline Frei Gaspar & 0,590 & 6.026 & Yes & http://www.freigaspar.mg.gov.br/ \\
\hline
\end{tabular}


Available online at www.managementjournal.info

\begin{tabular}{|c|c|c|c|c|}
\hline Fronteira dos Vales & 0,592 & 4.743 & Yes & http://www.fronteiradosvales.mg.gov.br/ \\
\hline Itaipé & 0,552 & 12.651 & Yes & http://itaipe.mg.gov.br/ \\
\hline Ladainha & 0,541 & 18.066 & Yes & http://www.ladainha.mg.gov.br/ \\
\hline Machacalis & 0,640 & 7.228 & Yes & http://www.machacalis.mg.gov.br/ \\
\hline Malacacheta & 0,618 & 19.173 & Yes & http://www.malacacheta.mg.gov.br/ \\
\hline Nanuque & 0,701 & 41.808 & Yes & http://nanuque.mg.gov.br/ \\
\hline $\begin{array}{c}\text { Novo Oriente de } \\
\text { Minas }\end{array}$ & 0,555 & 10.839 & Yes & http://www.novoorientedeminas.mg.gov.br/ \\
\hline Ouro Verde de Minas & 0,595 & 6.118 & No & N/A \\
\hline Pavão & 0,627 & 8.724 & Yes & http://www.pavao.mg.gov.br/portal1/intro.asp \\
\hline Poté & 0,624 & 16.573 & Yes & http://wwn=100131568 \\
\hline $\begin{array}{c}\text { Santa Helena de } \\
\text { Minas }\end{array}$ & 0,567 & 6.387 & Yes & $\mathrm{http}: / /$ santahelenademinas.mg.gov.br/site/ \\
\hline Setubinha & 0,542 & 11.952 & Yes & $\mathrm{http}: / /$ setubinha.mg.gov.br/portal/ \\
\hline Serra dos Aimorés & 0,651 & 8.789 & Yes & http://pmsa.mg.gov.br/ \\
\hline TeófiloOtoni & 0,701 & 141.502 & Yes & http://www.teofilootoni.mg.gov.br/site/ \\
\hline Umburatiba & 0,638 & 2.718 & No & N/A \\
\hline
\end{tabular}

Note: Not Applicable (N / A)

${ }^{*}$ ) IBGE (Brazilian Census Bureau) - estimated population for 2016

As shown in Table 1, it can be verified that of the 23 municipalities, 20 had official websites and adopt Electronic Government strategies, in addition to the fact that all have a lower HDI than Brazil, classified as medium human development. The municipalities that did not have a site are among the six least populous of the mesoregion, being worth mentioning the municipalities of Bertópolis, Fronteira dos Vales and Frei Gaspar, which have a site even though they are among the least populated.

When checking the sites of city halls, we came across basic tools of web 1.0, included in the concept of Electronic Government as providing information on municipalities, public agencies and management structure. When evaluating the "Home Pages" of the municipalities' websites, it was verified that the most frequently available links are: "Transparency Portal" or "Transparency", available on 19 sites; "The City" or "City" on 13, "Contact" on 11, "Bids" and "City Hall" on 9, "News" on 8. Also, "Legislation", "Useful Links", "Secretariats" and "Services" were made available by 7 municipalities.

It was identified that almost all city halls that had a website provided transparency links titled "Transparency" or "Portal of Transparency" in their initial pages, meeting the requirements of Brazilian Law No. 12,527, of November 18, 2011, which regulates the access to information provided in Article 216 of the Brazilian Federal Constitution. Only the municipality of Pavão does not provide any link connected to "Transparency." Through these data we can see that the Fiscal Responsibility Law can be one of the main motivations for municipalities to develop Electronic Government programs. It is worth noting that the efficiency of these links, such as how information was updated and how it works, was not analyzed.

Based on the evaluation of the "Initial Pages" of the sites, we verified that only the Teófilo Otoni municipality website offers links that are segmented by type of user ("Tourist", "Citizen", "Entrepreneur" and "Server"), According to the profile, all the other 19 municipalities that own a site make available and organize the links by type of information of the municipalities (for example: "City", "Secretaries", "News" and "Legislations").

One of the main objectives of Electronic Government is the provision of online services that avoid or reduce the need for citizens to go to public agencies to obtain information and documents that they need to carry out their daily activities. Based on this objective, when analyzing the sites of the 20 municipalities that own the tool, we find that only 8 (Ataléia, Carlos Chagas, Catuji, Crisólita, Frei Gaspar, Machacalis, Santa Helena and Teófilo Otoni) have the "Services" link in their Pages Initials. In the site of Machacalis there is the link for Services, but it does not have any information.

Among the services most frequently presented in these sites are: "Bids" available on 5 sites; "Transparency Portal" and "WebMail" in 3. Only the TeófiloOtoni prefecture provides online services (such as Negative Certificate related to debits, Urban Land and Building Tax (IPTU) Certifications, and Compulsory Notification) that could reduce the flow of people in the city. Thus, we find that most of the sites are means of disseminating information about municipalities (e.g. history, events and news) 
and institutional information of prefectures (e.g. departments, managers and legislations).

After analyzing the basic tools related to Electronic Government, it was sought to identify which basic types of citizen participation were offered by the municipalities in their sites, attending to the concept of electronic participation and Web 2.0, which are tools that allow the exchange and construction of information between government and citizens. The tools analyzed for this identification were, initially, the "Contact Us" and the "Ombudsman", which represent basic forms of interaction recurrently found in institutional electronic portals. In this research we consider "Contact Us", the links that directed to pages that allowed the information (messages) to be sent to the prefectures and "Ombudsman", the links and pages that allowed the exchange of information, that is, the citizen with possibility to a response to the information that was forwarded. The main function of the ombudsman is to 'listen' to the manifestation about the services provided, intervening in the relationship between the user and the public administration [31]. In table 2 we have the incidence of these tools in the sites of municipalities.

Table 2: Incidence of "contact us" and "ombudsman" on the sites of the municipalities of mucuri valley mesoregion

\begin{tabular}{|c|c|c|}
\hline Municipality & Contact Us & Ombudsman \\
\hline ÁguasFormosas & Yes & Yes \\
\hline Ataléia & No & No \\
\hline Bertópolis & Yes & No \\
\hline Carlos Chagas & Yes & No \\
\hline Catuji & No & No \\
\hline Crisólita & No & No \\
\hline Frei Gaspar & No & No \\
\hline Fronteira dos Vales & Yes & No \\
\hline Itaipé & No & No \\
\hline Ladainha & Yes & No \\
\hline Machacalis & Yes & Yes \\
\hline Malacacheta & No & No \\
\hline Nanuque & Yes & No \\
\hline Novo Oriente de Minas & Yes & No \\
\hline Pavão & Yes & No \\
\hline Poté & Yes & No \\
\hline Santa Helena de Minas & Yes & No \\
\hline Serra dos Aimores & No & No \\
\hline Setubinha & Yes & Yes \\
\hline
\end{tabular}

Based on the analysis performed on the sites of the prefectures of Mucuri Valley Mesoregion, we noticed that there is no type of standardization between sites. As it can be seen from the information shown in the table above, 12 of the municipalities provided the tool "Contact Us" and only 4 had "Ombudsman". As for the availability of tools, different forms of presentation were observed.

Based on the definition of "Contact Us" presented above, 12 prefectures made the tool available in different ways. Águas Formosas, Bertópolis, Carlos Chagas, Pavão and Poté, provided the tool with a link called "Talk to us". Ladainha, Machacalis, Nanuque, Novo Oriente de Minas, Serra dos Aimores and TeófiloOtoni, provided the tool with a link called "Contact". The municipality of Fronteira dos Vales differed from the others calling the tool as "Request Information". All these tools provided by these municipalities give the citizen the possibility of sending information to the city from a simple online form that requests basic information such as name, e-mail and the message to be forwarded. Some sites requested other information such as address, phone number and date of birth.

On the websites of the prefectures of Ataleiia, Catuji and Itaipé, links called "Contacts" were made available and in the city of Crisólita a " Talk to Us " link was available, but they were not considered a web 2.0 tool that allowed citizens to interact with municipalities, Since these spaces were used only for the dissemination of information such as telephone, e-mail and addresses of municipalities, not being possible for the citizens to send information. The municipality of Setubinha had a link "Contact", but was unavailable during the period of data collection for the survey. 
The tool "Ombudsman" was available on 4 sites. The city of ÁguasFormosas and Catuji had the link in their initial pages, where the citizen needed to fill out a simple form with the information name, e-mail, type of message and the message to be sent. In the form of the city of Catuji, besides this information, the telephone number, subject and the sector of destination were requested.

On TeófiloOtoni's website, the "Ombudsman" link was not available on the homepage; its location was hidden in a link called "Certificates" which, in turn, had a link called "Ombudsman Process Opening". To access this link the user had to follow a path through the site: citizen \Citizen's Portal \ Certifications \ Ombudsman Process Opening. In order to access the form the user had to register on the site. The form requested the following information: nature, subject, person interested, summary and description.

The municipality of Malacacheta provided the link to "Ombudsman" on its home page and differs from others by calling the page "Citizen Speech", where the user had the possibility to send an anonymous message or fill out a form with name, e-mail, contact phone, address, subject, contact type, and a field for message description. In addition to the possibility of sending messages, the page also provided a field to consult the ombudsman's progress, the number of calls made by "Citizen Speech", separated by ombudsman's messages received and answered. On the day of data collection, the tool "Citizen Speech" had received 35 communications and answered 32 .

The prefectures of Bertópolis and Carlos Chagas had the link "Ombudsman" in their initial pages, but were not considered as web 2.0 tools since they were unavailable during the period of data collection of the research.Frei Gaspar and Santa Helena de Minas did not provide a link called "Contact Us" and / or "Ombudsman", and no web 2.0 tools were found that would allow the exchange and / or construction of information between citizens and the municipal public administration.

In general, as far as the present research is concerned, the "Contact us" and "Ombudsman" tools that are available on the municipalities of the Mucuri Valley Mesoregion are characterized as basic web 2.0 tools for "symbolic" electronic participation for expression of feelings, wishes and demands, without, however, demonstrating their role in the construction of management in which the citizens' empowerment towards public management is truly perceived.

In short, the sites of the prefectures of the microregion of the Mucuri Valley mesorigion are characterized as basic tools of Electronic Government to make available information about the municipalities and their management. Regarding electronic participation, no more interactive web 2.0 tools were identified, such as participatory budgeting, participative planning, and participative educational plan or citizen participation forums.

After analyzing tools developed and made available by the city halls themselves, the use of web 2.0 tools on virtual social networking sites such as Face book, Twitter and Instagram were analyzed, which are free access tools and allow interactions and communications between users and the prefectures. In table 3, it is shown the list of prefectures that had virtual social networks, increasing the possibilities of participation to the user.

Table 3: Incidence of municipalities that use social networks in the teófilootonimicroregion

\begin{tabular}{|c|c|}
\hline Municipality & Social Networks \\
\hline ÁguasFormosas & $\mathrm{F} ; \mathrm{G}+; \mathrm{I}$ \\
\hline Ataléia & $\mathrm{F} ; \mathrm{I}$ \\
\hline Bertópolis & $\mathrm{N} / \mathrm{A}$ \\
\hline Carlos Chagas & $\mathrm{N} / \mathrm{A}$ \\
\hline Catuji & $\mathrm{F} ; \mathrm{I}$ \\
\hline Crisólita & $\mathrm{F}$ \\
\hline Franciscópolis & $\mathrm{F}$ \\
\hline Frei Gaspar & $\mathrm{N} / \mathrm{A}$ \\
\hline Fronteira dos Vales & $\mathrm{F}$ \\
\hline Itaipé & $\mathrm{F} ; \mathrm{Y}$ \\
\hline Ladainha & $\mathrm{F}$ \\
\hline Machacalis & $\mathrm{F}$ \\
\hline Malacacheta & $\mathrm{Y}$ \\
\hline Nanuque & $\mathrm{N} / \mathrm{A}$ \\
\hline
\end{tabular}




\begin{tabular}{|c|c|}
\hline Novo Oriente de Minas & N/A \\
\hline Ouro Verde de Minas & N/A \\
\hline Pavão & G \\
\hline Poté & F \\
\hline Santa Helena de Minas & N/A \\
\hline Serra dos Aimores & F \\
\hline Setubinha & F $;$ Y \\
\hline TeófiloOtoni & N/A \\
\hline
\end{tabular}

Note: Google + (G +), Instagram (I); Face book (F); YouTube (Y); Not Applicable (N / A).

As we can verify from the table above, most prefectures used social networks as a means of expanding their possibilities of communication with society. We found that 13 towns used Facebook, 2 Google +, 4 Instagram, 4 Youtube and 8 none of the social networks surveyed. The municipalities with the most social networks were ÁguasFormosas and TeófiloOtoni. None of the prefectures used Twitter, Linkedin and flickr. One fact worth mentioning is that the prefecture of Franciscopolis does not have an official website, but it has a Facebook page to show photos, news and events available. In turn, the use of these networks by some prefectures regarding their citizens is in the field of symbolism because they only allow access to information available to be consulted. No form of interaction and exchange of information between municipalities and citizens through these platforms exist.

The prefectures of Ouro Verde de Minas and Umburatiba do not have any type of online tool to provide information to citizens.

\section{Conclusion}

The objective of this research was based on the discussion about the concepts of electronic participation tools in web 2.0 platforms as an instrument of participation (or involvement) of the citizens in the public management and research in the sites of the prefectures of Mucuri Valley mesoregion to verify the availability of these tools of Electronic Government and electronic participation considering low levels of Human Development Index.

The results of the research demonstrate the need to expand the use of electronic participation tools in the Mucuri Valley mesoregion as a way to allow greater citizen participation in public management, since the prefectures of the mesoregion use only basic web 2.0 tools for Electronic Government and electronic participation. The prefectures of Francisco polis, Ouro Verde de Minas and Umburatiba do not have a site in the very
XXI century, where we experience the constant transformations and evolutions from globalization.

The prefectures that have official websites used them only for the dissemination of information. Only 12 of the prefectures provided "Contact Us," and 4 provided "Ombudsman". We verified that none of the city halls provided more interactive web 2.0 tools such as participatory budgeting, participative planning, and participative educational plan or citizen participation forums. Of the prefectures that used social network, the most used is Face book.

This research contributes for the understanding and discussion of the concepts of Electronic Government and electronic participation, a field still under construction in the area of the development of research on public management. In addition, it allows the knowledge of e-government practices adopted by the prefectures of the mesoregion object of this study. Finally, it can serve the citizens interested in participation as a way to demand from the public management itself the development of spaces and electronic tools that meet the progress of citizen participation in the municipal management of their respective cities.

This research was limited to the analysis of the existence of the tools in the sites of prefectures. No method was applied to investigate the use of these tools by citizens, and it is not possible to define their degree of use and applicability. Although some prefectures have social networks, it is not possible to predict the actions that can be developed by the citizens from the availability of these tools, since this study did not carry out any verification of their participative use.

From this study it is suggested the application of this method of research in other regions of the world, and comparisons and investigations of good practices can be carried out with the purpose of contributing 
to the expansion of the possibilities of citizen participation in Brazilian municipal management and also through carrying out

\section{References}

1. Silveira HFR (2000) A study of the power in the information society. Ciência da Informação. set./dez;29(3):79-90.

2. Antos M (2000) Por uma outra globalização: do pensamento único à consciência universal. Rio de Janeiro: Record (2).

3. ICT (2016) Facts and Figures [Internet]. 2016 [cited 2017 Apr 7]. Available from: http://www.itu.int/en/ITU-

D/Statistics/Pages/facts/default.aspx

4. Guimarães TA, Medeiros PHR (2005) A relação entre governo eletrônico e governança eletrônica no governo federal brasileiro. Cadernos EBAPEBR.3(4):01-18.

5. Oliveira TPS (2008) Participação Popular Via Internet: O Próximo Passo Do Governo Eletrônico? In: Democracia eletrônica. In: LEFIS SERIES 13: Prensas Universitarias de Zaragoza159-78.

6. IBGE (2014) Brazilian Institute of Geography and Statistics.National Household Sample Survey [Internet]. [cited 2017 Jul 7]. Available from: http://www.ibge.gov.br/english/estatistica/populacao/ trabalhoerendimento/pnad2014/default.shtm

7. United Nations UN (2012) e-government survey 2012: e-government for the people. New York: Department of Economic and Social Affairs.

8. Colombo C (2006) Inovación democrática y TIC: hacia uma democracia participativa? IDP Revista de Internet, Derecho y Política. (3):28-39.

9. Lupia A (2009) Can online deliberations improve politics? Scientific foundations for success. In: DAVIES, T; GANGADHARAN, S P (Eds) Online deliberation: Design, research, and practice.;(Stanford, California: Center for the Study of Language and Information).

10. Diniz EH, Barbosa AF, Junqueira ARB, Prado O (2009) Electronic government in Brazil: a historical perspective from a structured model of analysis. Revista de Administração Pública; 43(1):23-48.

11. Almarabeh T, AbuAli A (2010) a general framework for e-government: definition maturity challenges, opportunities, and success. European Journal of Scientific Research. 39(1):29-42.

12. OECD (2014) Recommendation of the Council on Digital Government Strategies. Paris: OECD 9.

13. Helbig N, Gil-García JR, Ferro E (2009) Understanding the complexity of electronic government: Implications from the digital divide literature. Government Information Quarterly.26 (1):89-97. researches that would analyze the degree of use and harnessing of electronic participation tools.
14. Borge R (2005) La Participación Electrónica: Estado de la cuestión y aproximación a su clasificación. Revista Derecho y Política.; Barcelona (1): UOC.

15. Sampaio MA, Pinho JAG, Santos EM, Sampaio Filho MC (2014) Digital participation and electronic government: Opening for what kind of citizenship? Revista Brasileira de Administração Científica.5(2):214-25.

16. Vaz JC (2005) Governança eletrônica: para onde é possível caminhar? Boletim Dicas, Instituto Pólis.

17. Barbosa A, Getschko D, Gatto R (2010) Internet e cidadania: A importância dos espaços virtuais no seu exercício. In: CGI.br Pesquisa sobre o uso das Tecnologias da Informação e da Comunicação no Brasil 2005-2009. 2010;São Paulo: Comitê Gestor da Internet no Brasil.

18. Azizan N, Smith R, Cooper V (2011) Critical success factors for knowledge transfer via government websites. Journal of e-Government Studies and Best Practices. 12

19. Santos JCS, Silva RRG (2011) Electronic government and political participation in the member's websites of the legislative assembly of Bahia. Informação \& Sociedade, João Pessoa. 21(1):215-24

20. Carniello M (2014) Análise das Diretrizes do Governo Eletrônico no Brasil. In: In: XII Congresso ALAIC. Lima, Peru.

21. O'reilly T (2005) what is Web 2.0: Design patterns and business models for the next generation of software. http://www oreillynet com/pub/a/oreilly/tim/news/2005/09/30/what-is-web$20 \mathrm{html}$.

22. Anderson P (2007) What is Web 2.0? Ideas, technologies and implications for education. JISC Technology and Standards Watch, 2007 [Internet]. [cited 2017 Apr 7]. Available from: http:/www.jisc.ac.uk/publications/documents/twweb 2.aspx

23. Deckert C (2014) A Utilização das Mídias Sociais Digitais pela Comunicação Pública como Forma de Engajamento do seu Público de Interesse. Comunicação \& Mercado. dez;3(8):04-15.

24. Recuero R (2009) Redes sociais na internet. Porto Alegre: Sulina.

25. Stevens H (2007) Business Innovation Will Come from Organizational Openness, Say Gartner. Gartner Group Press Release. Cannes, França, Novembers, [Internet]. 2007 [cited 2017 Apr 7]. Available from: http://www.gartner.com/it/page.jsp? id $=541907$ 
26. IBGE (2017) Brazilian Institute of Geography and Statistics [Internet]. DATASUS Tecnologia da Informação a Serviço do SUS. [cited 2017 Feb 2]. Available from: http://tabnet.datasus.gov.br/cgi/deftohtm.exe?ibge/cn v/poptMG.def

27. Tavares W, Paula APP (2014) Participação cidadã na gestão pública via internet. VII Congresso de Gestão Pública.27.

28. Bardin L (2009) Análise de conteúdo, ed. rev. Atual Lisboa: Editora Edições.70:281.
29. Tavares W, Cerquinho KG, Paula APP (2015) Participação Virtual na Gestão Pública no Âmbito Municipal: uma Análise dos Portais Eletrônicos das Capitais Brasileiras. In Belo Horizonte.

30. Cerquinho KG (2014) Governo eletrônico: a gestão da relação Estado-Sociedade no uso da internet. [Belo Horizonte]: Universidade Federal de Minas Gerais.

31. Peixoto SF, Marsiglia RMG, Morrone LC (2013) Ombudsman's attributions: the opinion of users and ombudsmen. Saúde e Sociedade. 22(3):785-94. 